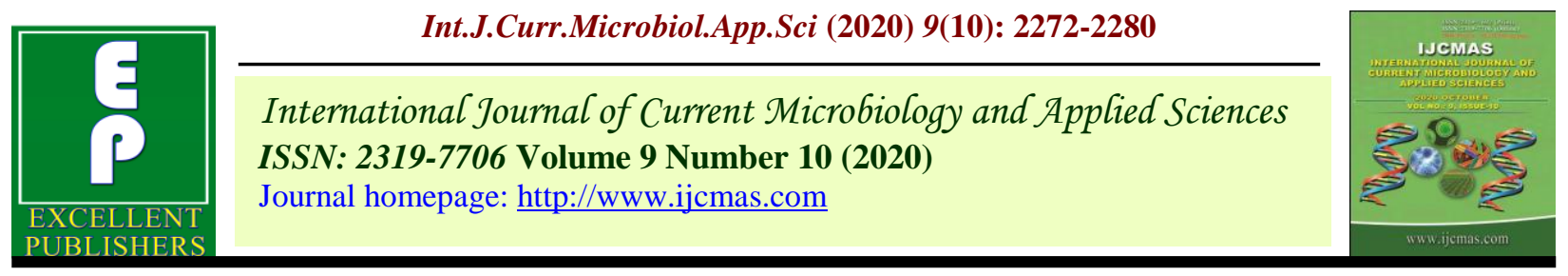

Original Research Article

https://doi.org/10.20546/ijcmas.2020.910.275

\title{
Development of Multiplex Microsatellite Marker Sets in Soybean [Glycine max (L.) Merr.]
}

\author{
Shipra Deo ${ }^{1}$, Anto James ${ }^{1}$, Sanjeev Kumar Singh ${ }^{1}$, \\ C.B. Singh ${ }^{2}$ and Mukesh Kumar Rana ${ }^{1 *}$ \\ ${ }^{1}$ ICAR-National Bureau of Plant Genetic Resources, Pusa Campus, New Delhi 110012 \\ ${ }^{2}$ Department of Botany, TilkaManjhi Bhagalpur University, Bhagalpur, Bihar812007, India \\ *Corresponding author
}

\begin{abstract}
A B S T R A C T
Multiplex PCR (mPCR) analyzes several markers simultaneously in a single reaction. The development of an SSR multiplex system requires estimation of range of allele sizes of different markers for their grouping into multiplex sets. In the present investigation duplex, triplex, quadruplex, and pentaplex combinations of SSR markers were optimized for mPCR using four different soybean genotypes namely, JJS 335, Durga, MACS 124 and JS 90-41.Twenty SSR markers distributed across all linkage groups of soybean were used to develop 22 multiplex sets of markers. These 22 multiplex sets comprised of twelve duplex, five triplex, four quadruplex and one pentaplex assays. Each band of mPCR was considered a single genetic marker and using all mPCR marker sets bands in the size range of 100-300bp were observed. The methodology used was quite systematic, rapid, reliable, and appropriate for qualitative detection and can be extended for multiplex development in other plant species having SSR marker technology for efficient plant genetic resources management including genetic diversity analysis, cultivar identification and evolutionary studies in plants.
\end{abstract}

\section{Keywords}

Multiplex PCR, PCR optimization, Glycine $\max \mathrm{L}$. , SSR markers

Article Info

Accepted:

17 September 2020 Available Online: 10 October 2020

\section{Introduction}

Multiplex Polymerase Chain Reaction (mPCR) is a molecular biology technique which amplifies several targets in a single PCR reaction. Chamberlain et al., (1988) described MPCR for the first time as a method for detection of deletion in the Dystrophin gene. mPCR uses several primer setswhich target multiple sequences of DNA and amplify in the same reaction tube at the same time and at the same annealing temperature. Due to simultaneous amplification, multiplex PCR is fast, simple, reliable, accurate, specific, sensitive, highly efficient, less costly and requires very minimal amount of DNA for PCR amplification. MPCR has been applied in several molecular biology 
applications like linkages analysis (Reis, 1991), SSR/SNP analysis (Moykishev et al., 2001;Mayden et al., 2008), molecular species identification (Staudacher et al., 2011), GMO identification (Mazur et al., 2017) etc.

SSRs or microsatellite markers have now become the marker of choice for genetic analyses owing to their abundance, high polymorphism rate, ease to use and high reproducibility. SSRs are short tandem repeats of mononucleotides to hexanucleotides with varying length of repeat motifs. Akkaya et al., (1992) reported SSRs in soybean for the first time. Thereafter, Diwan and Cregan (1997) reported the presence of microsatellites in a number of plant species and suggested their potential for numerous applications. Analyzing each SSR marker is time consuming and cumbersome which can be overcome by employing mPCR. Multiplex PCR assays have been reported in soybean particularly for screening genetically modified organism. For example, triplex and quadruplex PCR was optimized in soybean by Kutateladze et al., (2013), Datukishvili et al., (2015) and Lisha et al., (2017). Koppel et al., (2012) used pentaplex PCR for GMO detection in soybean. Sayama et al., (2011) designed a panel of 304 SSR markers using quadruplex PCR. The aim of this study, however, was to develop and optimize the multiplex sets of SSR markers in soybean to test their ability for amplification in single and multiplex PCR reactions particularly for genetic diversity assessment and cultivar identification.

\section{Materials and Methods}

\section{Plant materials}

Four soybean [Glycine max (L.) Merr.] varieties viz., JS 335, Durga, MACS 124 and JS-90-41 were selected from the polymorphism surveys of 96 Indian soybean varieties using 49 SSR markers on the basis of their unique and different amplicon sizes. These varieties have been released over different time periods for different agroclimatic regions in the country by different soybean breeding centers.

\section{DNA extraction}

Total genomic DNA was isolated from 10-15 days old young and tender leaves following CTAB (CetylTrimethyl Ammonium Bromide) method with some modifications as described by Saghai Maroof et al., (1984). The quality estimation of extracted DNA was accomplished by comparing the intensity of ethidium bromide- stained DNA bands on $0.8 \%$ agarose gel. The quantity of extracted DNA was further evaluated using absorbance measurements at 260 and $280 \mathrm{~nm}$ through NanoDrop ${ }^{\mathrm{TM}} 1000$. Final concentration was adjusted to $10 \mathrm{ng} \mu \mathrm{l}^{-1}$ for further use in PCR.

\section{Primer screening}

A total of 20 SSR markers distributed across the entire linkage map of soybean were used (Cregan et al., 1999). These markers were selected on the basis of their $\mathrm{G}+\mathrm{C}$ content, annealing temperature, PIC value and allele sizes observed from their PCR profile. The details of SSR markers are presented in Table 1. The allele size of each SSR primer was scored after amplification of each soybean genotype DNA with specific SSR primer in uniplex PCR. Thereafter, these 20 selected markers were finally combined to form duplex, triplex, quadruplex and pentaplex, for two, three, four and five marker combinations, respectively.

\section{Multiplex PCR (mPCR) optimization}

PCR conditions for duplex, triplex, quadruplex and pentaplex marker combinations were optimized. The master 
mix for mPCR was prepared in $2 \mathrm{ml}$ eppendrof tube then distributed in four PCR tubes and total volume of each PCR tube was made to $25 \mathrm{ml}$. PCR mixture consisted of $1 \mathrm{X}$ buffer, $3 \mathrm{mM} \quad \mathrm{MgCl}_{2}, \quad 0.25 \mathrm{mM}$ dNTPs mixture (dATP, dCTP, dGTP, dTTP), 0.5U Taq DNA polymerase and $0.5 \mu \mathrm{m}$ of each primer for duplex, triplex quadruplex and pentaplex mPCR. The template DNA concentration for mPCR varied from 40-100ng whereas for uniplex PCR with single primer pair, the template DNA concentration was $35 \mathrm{ng}$. Amplification was carried out in a peltierthermo cycler (Model PTC-200, M/S MJ Research). All multiplex PCR conditions had the same optimal cycling condition. PCR cycling conditions consisted of initial denaturation at $94^{\circ} \mathrm{C}$ for $5 \mathrm{~min}$ followed by 40 cycles, each cycle consisting of denaturation at $94^{\circ} \mathrm{C}$ for $1 \mathrm{~min}$, primer annealing at $55^{\circ} \mathrm{C}$ for $1 \mathrm{~min}$, elongation at $72^{\circ} \mathrm{C}$ for $1 \mathrm{~min}$. Finally, elongation step of PCR was carried out at $72^{\circ} \mathrm{C}$ for $8 \mathrm{~min}$. The amplification products were analyzed by electrophoresis in $3.0 \%$ high resolution agarose (metaphor) gel containing $0.5 \mathrm{mg} / \mathrm{ml}$ of ethidium bromide. 100bp DNA size standard was also loaded to assess the size of the amplicons generated by each SSR primer. The gel was run in $1 \mathrm{x}$ TAE buffer at $90 \mathrm{~V}$ for 60 min. DNA bands were visualized under UV transilluminator and photographed using gel documentation system (M/S Syngen).

\section{Results and Discussion}

Multiplex PCR is a transformation of the conventional PCR method. The basic principle of multiplex PCR is the same as that of the conventional PCR, except that several specific primers are combined in a single PCR reaction. The primers are specifically combined with their corresponding DNA template, and more than one DNA fragment amplified in one reaction simultaneously. Multiplex PCR (mPCR) analyzes several markers simultaneously in a single reaction. The development of an SSR multiplex system requires selection of sufficiently different sized markers for their grouping into multiplex sets. The quality, quantity and DNA extraction procedure form a critical factor in mPCR amplification. The DNA for MPCR of four soybean samples was extracted using CTAB method and was then quantified at $\mathrm{A}_{260} / \mathrm{A}_{280} \mathrm{~nm}$ absorbance. The concentration of DNA samples ranged from 1.7 to $2.0 \mathrm{ng} / \mu \mathrm{l}$ which indicated high quality of DNA preparation. Absorbance ratio exceeding this range indicates poor quality of the extracted DNA, which might create problems during PCR.

During mPCR the specificity and sensitivity of PCR is affected by many factors, such as the purity of the DNA, primer design, concentration of the corresponding primers, ratio of primers and annealing temperature. To optimize the multiplex sets of primers, equal concentration of component primers of a set was used in multiplex PCR so as to prevent generation of excessive quantities of primer dimers. No amplification was found in the multiplex reaction when increasing the annealing temperature to $70^{\circ} \mathrm{C}$. Keeping the annealing temperature at $55^{\circ} \mathrm{C}$ provided the reproducible PCR products. Annealing temperature when changed slightly $\left( \pm 2^{0} \mathrm{C}\right)$, PCR did not result in satisfactory output. Primers with the allele size difference of more than 30 bp were considered more suitable for mPCR. Combination of different SSR markers for duplex, triplex, quadruplex and pentaplex PCR were optimized using four soybean varieties namely, JS335, Durga, MACS 124 and JS 90-41.

The template DNA concentration was optimized because without appropriate concentration no amplification was observed. Template DNA concentration of 30ng generated weak bands when this 
concentration was used with two or more than two primers, so the concentration of template DNA was increased which resulted in corresponding increase in the intensity of the observed DNA bands. Genomic DNA concentration in the range of 40 to $100 \mathrm{ng}$ was used for different $\mathrm{mPCR}$ reactions which were 40ng for duplex, 60ng for triplex, 80ng for quadruplex and 100ng for pentaplex PCR.

On the basis these parameters, up to five SSR primers were included in a set. Sometimes samples could not be amplified with given marker set of duplex, triplex, quadruplex and pentaplex PCR (datanot shown) and hence were eliminated to be part of the set. Finally, a set of twenty-two marker combinations (Table 2) was selected on the basis of their successful amplification in the four individual soybean genotypes in a reaction. Out of these 22 sets, 12 multiplex sets were duplex, five triplex, four quadruplex and onepentaplex. Thesesets of multiplexed markers would enable detection of genetic diversity with high specificity in very short time.

DNA profiles of four soybean genotypes were generated and the observed band sizes ranged between $100-360 \mathrm{bp}$ (Table 2). Representative profiles for duplex, triplex, quadruplex and pentaplex PCR are shown in Figure 1 to 4 , respectively. It can be seen that the combination of markers SATT 244 and SATT 031 in duplex PCR amplified bands of sizes 170bp and120bp; 150bp, 180bp and $120 \mathrm{bp} ; 170 \mathrm{bp}$ and $120 \mathrm{bp}$; 150bpand 120bp, respectively for JS 335, Durga, MACS 124, and JS 90-41 soybean genotypes (Fig. 1). Similarly, the marker set of SATT 373 and SATT 177 in duplex PCR produced 220bp and 120bp bands for JS 335, 270bp and 100bp for Durga, 220bp and 100bp for MACS 124, and 270bp and 110bp for JS 90-41 (Table 2). In the triplex mPCR, SSR marker set SATT 373, SATT 335, SATT 309 generated bands in the size of 220bp, 160bp and 140bp for JS 335; and 270bp, 150bp and 140bpfor Durga. The band sizes were 220bp, 150bp and 140bp for MACS 124; and 270bp, 160bp and 140bp for JS 90-41 using this set of triplex markers (Fig 2). In quadruplex mPCR the set of four markers SATT 031, SATT 244, SATT 285 and SATT 268 was used which amplified fragments of sizes 120bp, 170bp, 200bp and 360bp for JS 335 (Fig 3). Band sizes of 120bp, 150bp, 180bp, 200bp and 340bp were amplified in Durga using this quadruplex set. Bands of sizes 120bp, 170bp, 200bp and $300 \mathrm{bp}$ for MACS 124 and 120bp, 150bp, 240bp and 320bp for JS 90-41were produced using this quadruplex set. In the pentaplex PCR, markers namely SATT 177, SATT 309, SATT 285, SATT 335 and SATT 268 were used which produced bands of sizes $120 \mathrm{bp}$, 140bp, 200bp, 160bp and 360bp for JS 335; $110 \mathrm{bp}, 140 \mathrm{bp}, 200 \mathrm{bp}, 150 \mathrm{bp}$, and 340bp for Durga;100bp, 140bp, 200bp, 150bp and $300 \mathrm{bp}$ for MACS 124; and 110bp, 140bp, 240bp, 160bp and 320bp for genotype JS 9041 (Fig 4).

In this study, mPCR has been optimized and established for the simultaneous detection of upto five marker loci in one reaction. Compared with regular PCR, mPCR shows many merits, including specificity, low cost, high efficiency, and reproducibility. Therefore, it can be applied in qualitative and quantitative studies, genetic diversity analyses, and identification of soybean cultivars and would result in saving time for marker detection and reducing the reagents' cost. 
Table.1 Details of multiplex primers used for multiplex PCR in soybean [Glycine max (L.)Merr.]

\begin{tabular}{|c|c|c|c|c|c|c|}
\hline S. No. & $\begin{array}{l}\text { Marker } \\
\text { name }\end{array}$ & $\begin{array}{l}\text { Linkage } \\
\text { group }\end{array}$ & $\begin{array}{c}\text { Chromosome } \\
\text { no. }\end{array}$ & $\mathrm{G}+\mathrm{C} \%$ & Forward primer & Reverse primer \\
\hline 1 & SATT031 & & 16 & & $\begin{array}{l}\text { GCGTGGCACCCTTG } \\
\text { ATAAATAA }\end{array}$ & $\begin{array}{l}\text { GCGCACGAAAGTTTT } \\
\text { TCTGTAACA }\end{array}$ \\
\hline 2 & SATT002 & D2 & 17 & $\begin{array}{l}\text { F-22.73\%, } \\
\text { R-27.78\% }\end{array}$ & $\begin{array}{l}\text { TGTGGGTAAAATAG } \\
\text { ATAAAAAT }\end{array}$ & $\begin{array}{l}\text { TCATTTTGAATCGTTG } \\
\text { AA }\end{array}$ \\
\hline 3 & SATT082 & D2 & 17 & $\begin{array}{l}\text { F-30.00\%, } \\
\text { R-40.00\% }\end{array}$ & $\begin{array}{l}\text { AATTCATTTAGGGA } \\
\text { GTTGAT }\end{array}$ & $\begin{array}{l}\text { CTAGCCAATGTCATA } \\
\text { TGACT }\end{array}$ \\
\hline 4 & SATT177 & A2 & 8 & $\begin{array}{l}\text { F-42.86\%, } \\
\text { R-50.00\% }\end{array}$ & $\begin{array}{l}\text { CGTTTCATTCCCAT } \\
\text { GCCAATA }\end{array}$ & $\begin{array}{l}\text { CCCGCATCTTTTTCAA } \\
\text { CCAC }\end{array}$ \\
\hline 5 & $\begin{array}{l}\text { GlySATT } \\
180\end{array}$ & $\mathrm{C} 1$ & 4 & $\begin{array}{l}\text { F-57.1\%, } \\
\text { R-33.3\% }\end{array}$ & TCGCGTTTGTCAGC & $\begin{array}{l}\text { TTGATTGAAACCCAA } \\
\text { CTA }\end{array}$ \\
\hline 6 & $\begin{array}{l}\text { GlySATT } \\
184\end{array}$ & D1a & 1 & $\begin{array}{l}\text { F-40.7\%, } \\
\text { R-42.4\% }\end{array}$ & $\begin{array}{l}\text { GCGCTATGTAGATT } \\
\text { ATCCAAATTACGC }\end{array}$ & $\begin{array}{l}\text { GCCACTTACTGTTACT } \\
\text { CAT }\end{array}$ \\
\hline 7 & SATT197 & B1 & 11 & $\begin{array}{l}\text { F-50.00\%, } \\
\text { R-32.00\% }\end{array}$ & $\begin{array}{l}\text { CACTGCTTTTTCCCC } \\
\text { TCTCT }\end{array}$ & $\begin{array}{l}\text { AAGATACCCCCAACA } \\
\text { TTATTTGTAA }\end{array}$ \\
\hline 8 & SATT244 & $\mathrm{J}$ & 16 & $\begin{array}{l}\text { F-39.29\%, } \\
\text { R-35.71\% }\end{array}$ & $\begin{array}{l}\text { GCGCCCCATATGTT } \\
\text { TAAATTATATGGAG }\end{array}$ & $\begin{array}{l}\text { GCGATGGGGATATTT } \\
\text { TCTTTATTATCAG }\end{array}$ \\
\hline 9 & $\begin{array}{l}\text { GlySATT } \\
267\end{array}$ & D1a & 1 & $\begin{array}{l}\text { F-50.00\%, } \\
\text { R-35.00\% }\end{array}$ & $\begin{array}{l}\text { CCGGTCTGACCTAT } \\
\text { TCTCAT }\end{array}$ & $\begin{array}{l}\text { CACGGCGTATTTTTAT } \\
\text { TTTG }\end{array}$ \\
\hline 10 & SATT268 & E & 15 & $\begin{array}{l}\text { F-36.00\%, } \\
\text { R-40.00\% }\end{array}$ & $\begin{array}{l}\text { TCAGGGGTGGACCT } \\
\text { ATATAAAATA }\end{array}$ & $\begin{array}{l}\text { CAGTGGTGGCAGATG } \\
\text { TAGAA }\end{array}$ \\
\hline 11 & SATT285 & $\mathrm{J}$ & 16 & $\begin{array}{l}\text { F-29.63\%, } \\
\text { R-37.93\% }\end{array}$ & $\begin{array}{l}\text { GCGACATATTGCAT } \\
\text { TAAAAACATACTT }\end{array}$ & $\begin{array}{l}\text { GCGGACTAATTCTAT } \\
\text { TTTACACCAACAAC }\end{array}$ \\
\hline 12 & $\begin{array}{l}\text { GlySATT } \\
300\end{array}$ & A1 & 5 & $\begin{array}{l}\text { F-47.8\%, } \\
\text { R-60.0\% }\end{array}$ & $\begin{array}{l}\text { GCGCCCACACAACC } \\
\text { TTTAATCTT }\end{array}$ & $\begin{array}{l}\text { GCGGCGACTGTTAAC } \\
\text { GTGTC }\end{array}$ \\
\hline 13 & SATT308 & M & 7 & $\begin{array}{l}\text { F-57.7\% } \\
\text { R-54.5\% }\end{array}$ & $\begin{array}{l}\text { GCGTTAAGGTTGGC } \\
\text { AGGGTGGAAGTG }\end{array}$ & $\begin{array}{l}\text { GCGCAGCTTTATACA } \\
\text { AAAATCAACAA }\end{array}$ \\
\hline 14 & SATT309 & G & 18 & $\begin{array}{l}\text { F-52.88\%, } \\
\text { R-41.67\% }\end{array}$ & $\begin{array}{l}\text { GCGCCTTCAAATTG } \\
\text { GCGTCTT }\end{array}$ & $\begin{array}{l}\text { GCGCCTTAAATAAAA } \\
\text { CCCGAAACT }\end{array}$ \\
\hline 15 & $\begin{array}{l}\text { GlySATT } \\
335\end{array}$ & $\mathrm{~F}$ & 13 & $\begin{array}{l}\text { F-50.00\%, } \\
\text { R-45.45\% }\end{array}$ & $\begin{array}{l}\text { CAAGCTCAAGCCTC } \\
\text { ACACAT }\end{array}$ & $\begin{array}{l}\text { TGACCAGAGTCCAAA } \\
\text { GTTCATC }\end{array}$ \\
\hline 16 & SATT 337 & $\mathrm{~K}$ & 9 & $\begin{array}{l}\text { F-22.73\%, } \\
\text { R-27.78\% }\end{array}$ & $\begin{array}{l}\text { GCGTAAATCTGATA } \\
\text { TATGTTACCACTGA }\end{array}$ & $\begin{array}{l}\text { GCGTAATACGCAAAA } \\
\text { CATAATTAGCCTA }\end{array}$ \\
\hline 17 & SATT373 & $\mathrm{L}$ & 19 & $\begin{array}{l}\text { F-34.78\%, } \\
\text { R-48.00\% }\end{array}$ & $\begin{array}{l}\text { TCCGCGAGATAAAT } \\
\text { TCGTAAAAT }\end{array}$ & $\begin{array}{l}\text { GGCCAGATACCCAAG } \\
\text { TTGTACTTGT }\end{array}$ \\
\hline 18 & $\begin{array}{l}\text { GlySATT } \\
449\end{array}$ & A1 & 5 & $\begin{array}{l}\text { F-38.5\%, } \\
\text { R-40.9\% }\end{array}$ & $\begin{array}{l}\text { GCGTGCTTCTTATA } \\
\text { TTAGGTGTTAGT }\end{array}$ & $\begin{array}{l}\text { GCGCATTGGAGTTTTT } \\
\text { GCTTTT }\end{array}$ \\
\hline 19 & $\begin{array}{l}\text { GlySATT } \\
586\end{array}$ & $\mathrm{~F}$ & 13 & $\begin{array}{l}\text { F-54.5\%, } \\
\text { R-43.5\% }\end{array}$ & $\begin{array}{l}\text { GCGGCCTCCAAACT } \\
\text { CCAAGTAT }\end{array}$ & $\begin{array}{l}\text { GCGCCCAAATGATTA } \\
\text { ATCACTCA }\end{array}$ \\
\hline 20 & $\begin{array}{l}\text { GlySATT } \\
588\end{array}$ & K & 9 & $\begin{array}{l}\text { F-45.8\%, } \\
\text { R-43.5\% }\end{array}$ & $\begin{array}{l}\text { GCTGCATATCCACT } \\
\text { CTCATTGACT }\end{array}$ & $\begin{array}{l}\text { GAGCCAAAACCAAAG } \\
\text { TGAAGAAC }\end{array}$ \\
\hline
\end{tabular}


Table.2 Multiplex sets of SSR markers in genotypes of soybean [Glycine max (L.)Merr.]

\begin{tabular}{|c|c|c|c|c|c|c|}
\hline \multirow{2}{*}{$\begin{array}{l}\text { Multiple } \\
\text { x set no. }\end{array}$} & \multirow{2}{*}{$\begin{array}{l}\text { No. of } \\
\text { markers }\end{array}$} & \multirow[t]{2}{*}{ SSR marker names } & \multicolumn{4}{|c|}{ Genotype band sizes (bp) } \\
\hline & & & JS335 & Durga & MACS124 & JS-90-41 \\
\hline 1 & 2 & $\begin{array}{l}\text { Gly SATT, 300, SATT } \\
002\end{array}$ & 250,140 & 270,140 & 250,140 & 250,145 \\
\hline 2 & 2 & SATT 373, SATT 177 & 220,120 & 270,110 & 220,100 & 270,110 \\
\hline 3 & 2 & SATT 197, SATT 373 & 170,220 & 170,270 & 140,220 & 170,270 \\
\hline 4 & 2 & $\begin{array}{l}\text { Gly SATT 267, Gly } \\
\text { SATT } 184\end{array}$ & 24,140 & 240,180 & 230,180 & 240,160 \\
\hline 5 & 2 & $\begin{array}{l}\text { Gly SATT } 449, \text { Gly } \\
\text { SATT } 588\end{array}$ & 250,180 & 240,180 & 250,150 & 260,180 \\
\hline 6 & 2 & SATT 268, SATT 373 & 360,220 & 340,270 & 300,220 & 320,270 \\
\hline 7 & 2 & SATT 308, SATT 268 & 150,360 & 170,340 & 170,300 & 170,320 \\
\hline 8 & 2 & SATT 285, SATT 268 & 200,360 & 200,340 & 200,300 & 240,320 \\
\hline 9 & 2 & SATT 244, SATT 031 & 170,120 & $150,180,120$ & 170,120 & 150,120 \\
\hline 10 & 2 & SATT 308, SATT 082 & 150,110 & 170,110 & 170,110 & 170,110 \\
\hline 11 & 2 & SATT 309, SATT 285 & 140,200 & 140,200 & 140,200 & 140,240 \\
\hline 12 & 2 & SATT 180, SATT 586 & 120,200 & 110,250 & 100,250 & 110,230 \\
\hline 13 & 3 & $\begin{array}{l}\text { SATT 082, SATT 002, } \\
\text { SATT197 }\end{array}$ & $110,140,170$ & $110,140,170$ & $110,140,140$ & $110,145,170$ \\
\hline 14 & 3 & $\begin{array}{l}\text { SATT } 373, \text { SATT } 335, \\
\text { SATT177 }\end{array}$ & $220,160,120$ & $270,150,110$ & $220,150,100$ & $270,160,110$ \\
\hline 15 & 3 & $\begin{array}{l}\text { SATT 309, SATT 285, } \\
\text { SATT268 }\end{array}$ & $140,200,360$ & $140,200,340$ & $140,200,300$ & $140,240,320$ \\
\hline 16 & 3 & $\begin{array}{l}\text { SATT } 373, \text { SATT } 335, \\
\text { SATT } 309\end{array}$ & $220,160,140$ & $270,150,140$ & $220,150,140$ & $270,160,140$ \\
\hline 17 & 3 & $\begin{array}{l}\text { SATT 285, SATT 335, } \\
\text { SATT } 177\end{array}$ & $200,160,120$ & $200,150,110$ & $200,150,100$ & $240,160,110$ \\
\hline 18 & 4 & $\begin{array}{l}\text { SATT } 309, \text { SATT } 373 \text {, } \\
\text { SATT } 335, \text { SATT } 268\end{array}$ & $\begin{array}{l}140,220,160, \\
360\end{array}$ & $\begin{array}{l}140,270,150, \\
340\end{array}$ & $\begin{array}{l}140,220,150, \\
300\end{array}$ & $\begin{array}{l}140,270,160 \\
320\end{array}$ \\
\hline 19 & 4 & $\begin{array}{l}\text { SATT } 309, \text { SATT } 244, \\
\text { SATT285, SATT } 268\end{array}$ & $\begin{array}{l}140,170,200, \\
360\end{array}$ & $\begin{array}{l}140,150,180 \\
200,340\end{array}$ & $\begin{array}{l}140,170,200, \\
300\end{array}$ & $\begin{array}{l}140,150,240 \\
320\end{array}$ \\
\hline 20 & 4 & $\begin{array}{l}\text { SATT } 177, \text { SATT } 285, \\
\text { SATT } 335, \text { SATT } 268\end{array}$ & $\begin{array}{l}120,200,160, \\
360\end{array}$ & $\begin{array}{l}110,200,150, \\
340\end{array}$ & $\begin{array}{l}100,200,150, \\
300\end{array}$ & $\begin{array}{l}110,240,160 \\
320\end{array}$ \\
\hline 21 & 4 & $\begin{array}{l}\text { SATT } 031, \text { SATT } 244, \\
\text { SATT285, SATT } 268\end{array}$ & $\begin{array}{l}120,170,200, \\
360\end{array}$ & $\begin{array}{l}120,150,180, \\
200,340\end{array}$ & $\begin{array}{l}120,170,200, \\
300\end{array}$ & $\begin{array}{l}120,150,240 \\
320\end{array}$ \\
\hline 22 & 5 & $\begin{array}{l}\text { SATT } 177 \text {, SATT } 309 \text {, } \\
\text { SATT } 285 \text {, SATT } 335 \text {, } \\
\text { SATT } 268\end{array}$ & $\begin{array}{l}120,140,200, \\
160,360\end{array}$ & $\begin{array}{l}110,140,200, \\
150,340\end{array}$ & $\begin{array}{l}100,140, \\
200,150,300\end{array}$ & $\begin{array}{l}110,140,240 \\
160,320\end{array}$ \\
\hline
\end{tabular}


Fig.1 Multiplex PCR amplification in four soybean [Glycine $\max (\mathrm{L}$.)Merr.] genotypes (1: JS335, 2: Dugra (JS-72-280), 3: MACS-124, 4: JS-90-41). M is 100 base pair DNA marker. A: duplex multiplex PCR using primer combinations SAT244 and SATT031, B: uniplex PCR amplification with SSR primer SATT244 and C: uniplex PCR amplification using SSR primer SATT031

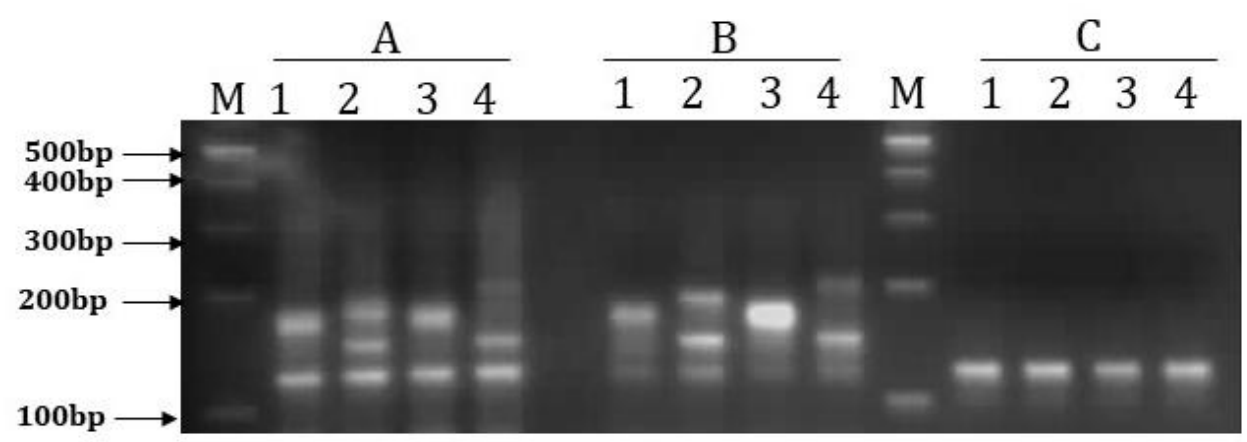

Fig.2 Multiplex PCR amplification in four soybean [Glycine max (L.)Merr.] genotypes (1: JS335, 2: Dugra (JS-72-280), 3: MACS-124, 4: JS-90-41). M is 100 base pair DNA marker. A: triplex multiplex PCR using primer combinations SATT373, SATT335 and SATT309, B: uniplex PCR amplification with SSR primer SAT373 and C: uniplex PCR amplification using SSR primer SATT335 and D: uniplex PCR amplification using SSR primer SATT309

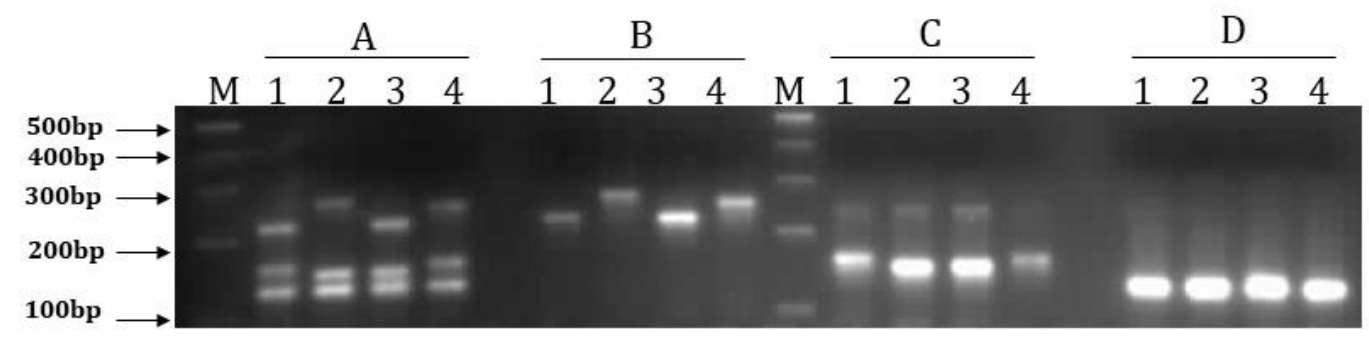

Fig.3 Multiplex PCR amplification in four soybean [Glycine max (L.)Merr.]genotypes (A: JS335, B: Dugra (JS-72-280), C: MACS-124, D: JS-90-41). M is 100 base pair DNA marker. Lane 1: quadruplex multiplex PCR using primer combinations SATT031, SATT244, SATT285 and SATT268 and lanes 2 to 4 are uniplex PCR amplifications using primers SATT031, SATT244, SATT285 and SATT268, respectively

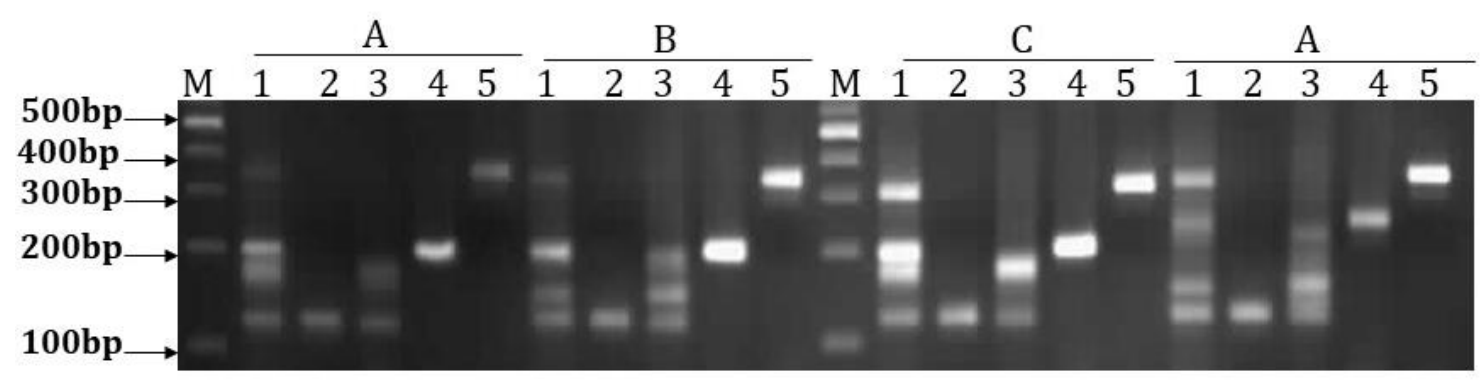


Fig.4: Multiplex PCR amplification in four soybean [Glycine max (L.)Merr.] genotypes (A: JS335, B: Dugra (JS-72-280), C: MACS-124, D: JS-90-41). M is 100 base pair DNA marker. Lane 1: pentaplex multiplex PCR using primer combinations SATT177, SATT309, SATT285, SATT335 and SATT268 and lanes 2 to 6 are uniplex PCR amplifications using primers SATT177, SATT309, SATT285, SATT335 and SATT268, respectively

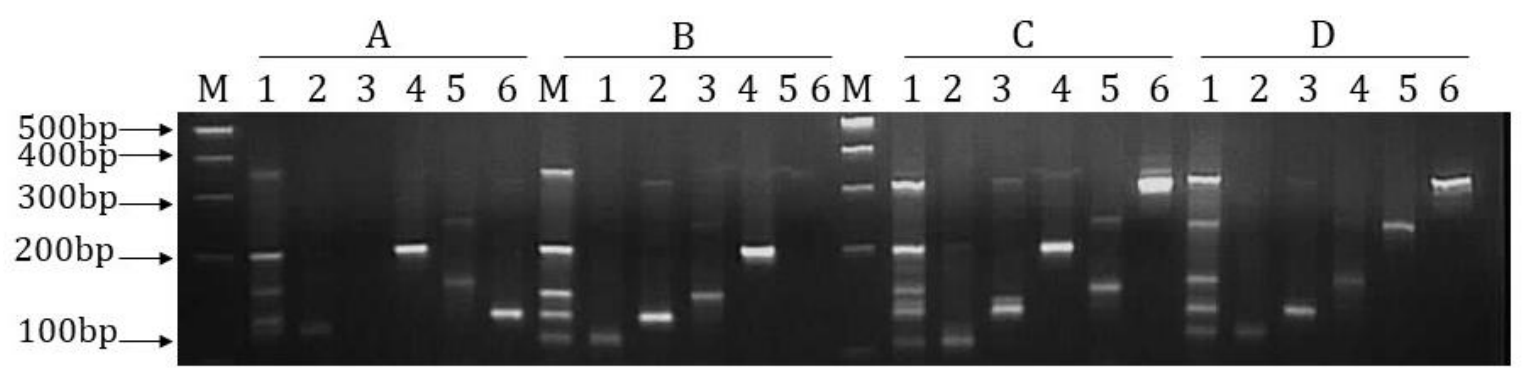

There are certain limitations of mPCR like multiple primer sets may lead to cross hybridization with each other and there is the possibility of mis-priming with other templates, self-inhibition among different sets of primers, low amplify ication efficiency, primer dimer formation, over lapping of amplicons sizes of template DNA etc. which may hinder the use of $\mathrm{mPCR}$ in many applications.

\section{Acknowledgements}

The authors are grateful to Director, ICARNational Bureau of Plant Genetic Resources to provide the laboratory facilities to undertake the work. Financial support received from Indian Council of Agricultural Research in terms of institutional project is duly acknowledged.

\section{References}

Akkaya MS, Bhagwat AA and Cregan PB. (1992). Length polymorphism of simple sequence repeats DNA in soybean. Genetics 47: 1131-1139

Chamberlain JS, Gibbs RA, Rainer JE, Nguyen PN, Caskey CT. (1988). Deletion screening of the Duchenne muscular dystrophy locus via multiplex DNA amplification. Nucleic Acids Research 16: 11141- 11156. DOI: 10. 1093/nar/ 16.23. 11141

Cregan PB, Jarvik T, Bush AL, Shoemaker RC, Lark KG, Kaya N, Vantoai TT, Lohmes, J. Chung DG and Specht JE. (1999). An integrated genetic linkage map of the soybean genome. Crop Science 39: 1464-1490 DOI. org/ 10.2135 / crop sci 1999. 395146x

Datukishvili N, Kutateladze T, Gabriadze I, Bitskinashvili $\mathrm{K}$ and Vishnepolsky V. (2015). New multiplex PCR methods for rapid screening of genetically modified organisms in foods. Original Research (6): 757 DOI: 10.3389/fmicb.2015.00757

Diwan N and Cregan PB. (1997). Automated sizing of fluorescent- labeled simple sequence repeat (SSR) markers to assay genetic variation in soybean. Theor Appl Genet (95): 723- 733

KöppelR, Franziska VV, Nora F and Thomas B. (2012). Multiplex real-time PCR for the detection and quantification of DNA from four transgenic soy Mon89788, A5547-127, Roundup Ready, A2704-12 and lectin. SpringerVerlag (222) 1Eur Food Res Technol DOI 10.1007/s00217-012-1730-y

Kutateladze T, Gabriazde I, Vishnepolsky B 
and Karseladze M. (2013). Development of triplex PCR for simultaneous detection of maize, wheat and soybean. Food Control 34: 698-702 DOI: 10. 1016/j. foodcont. 2013.06.018

Lisha V, New CY, Nishibuchi M and Son R. (2017). Rapid genetically modified organism (GMO) screening of various food products and animal feeds using multiplex polymerase chain reaction (PCR). Food Research 1: 1-8 DOI 10.26656/ fr.2017.1.001

Mayden RL, Chen WJ, Bart HL, Doosey MH, Simons AM, Tang KL, Wood EM, Agnew MK, Yang L, Hirt MV, Clements D, Saitoh K, Sado T, Miya $M$ and Nishida M. (2008). Reconstructing the phylogenetic relationships of the earth's most diverse clade of freshwater fishesorder cyprini forms (Actionpterygii: ostariophysis): a case study using multiple nuclear loci and the mitochondrial genome. Mol Plylogene Evol: 51: 500-514

MazurM, Sieradzki Z, KrólB and Kwiatek K. (2017). Multiplex PCR assays for qualitative detection and identification of the GT73, Ms8, Rf3 and T45 varieties of genetically modified oilseed rape. Journal of Animal and
Feed Sciences, 26: 148-156.

Myakishev MV. (2001). High-throughput SNP genotyping by allele-specific PCR with universal energy-transferlabeled primer. Genome Research 11: 163-169. DOI: 10. 1101/gr. 157901

Reis A. (1991). PCR in linkage analysis of genetic diseases. PCR Topics. Pp. 7579. DOI: 10.1007/978-3-642-75924-6_ 15.

Saghai-Maroof MA, Soliman KM, Jorgensen RA and Allard RW. (1984). Ribosomal DNA spacer-length polymorphism in barley: Mendelian inheritance, chromosomal location, and population dynamics, Proc. Natl. Acad. Science. 81: 8014-8018.

Sayama, T, T. Y. Hwang, K Komatsu, YTakada, Takahashi M, Kato S, Sasama H, Higashi A, Nakamoto Y, Funatsuki H, and Ishimoto M. (2011). Development and Application of a whole -Genome Simple Sequence Repeat Panel for High Throughput Genotyping in Soybean DNA Research (18)107-15 DOI: 10. 1093/dnare (2): s/dsr003

Staudacher, K, Pitterl P, Furlan L, Cate P and Traugott M. (2011). PCR based species identification of Agriotes larvae. Bulletin of Entomological Research, 101: 201-210.

\section{How to cite this article:}

Shipra Deo, Anto James, Sanjeev Kumar Singh, C.B. Singh and Mukesh Kumar Rana. 2020. Development of Multiplex Microsatellite Marker Sets in Soybean [Glycine max (L.) Merr.]. Int.J.Curr.Microbiol.App.Sci. 9(10): 2272-2280. doi: https://doi.org/10.20546/ijcmas.2020.910.275 